\title{
Paenibacillus castaneae sp. nov., isolated from the phyllosphere of Castanea sativa Miller
}

\author{
Angel Valverde, ${ }^{1}$ Alvaro Peix, ${ }^{1}$ Raúl Rivas, ${ }^{2}$ Encarna Velázquez, ${ }^{2}$ \\ Sergio Salazar, ${ }^{1}$ Ignacio Santa-Regina, ${ }^{1}$ Claudino Rodríguez-Barrueco ${ }^{1}$ \\ and José M. |gual ${ }^{1}$ \\ ${ }^{1}$ Instituto de Recursos Naturales y Agrobiología de Salamanca, Consejo Superior de \\ Investigaciones Científicas (IRNASA-CSIC), Salamanca, Spain \\ ${ }^{2}$ Departamento de Microbiología y Genética, Universidad de Salamanca, 37007 Salamanca, Spain
}

Correspondence

José M. Igual mariano.igual@irnasa.csic.es

\begin{abstract}
A bacterial strain, designated Ch- $32^{\top}$, was isolated from the phyllosphere of Castanea sativa in Spain. Phylogenetic analysis based on 16S rRNA gene sequences placed the isolate in the genus Paenibacillus within the same subgroup as Paenibacillus xinjiangensis and Paenibacillus glycanilyticus, with similarities of 96.3 and $96.8 \%$, respectively. DNA-DNA hybridization values for strain $\mathrm{Ch}-32^{\top}$ with these two species were lower than $20 \%$. The novel isolate was a Gramvariable, motile, sporulating rod. It produced catalase and oxidase and hydrolysed cellulose, gelatin and aesculin. Acetoin and urease production, nitrate reduction and starch hydrolysis were negative. Growth was supported by many carbohydrates and organic acids as carbon sources. MK-7 was the only menaquinone detected and anteiso- $C_{15: 0}$, iso- $C_{16: 0}$ and $C_{16: 0}$ were the major fatty acids. The DNA G +C content was 46 mol\%. Phylogenetic, DNA relatedness and phenotypic analyses showed that strain $\mathrm{Ch}-32^{\top}$ should be classified as a novel species of the genus Paenibacillus, for which the name Paenibacillus castaneae sp. nov. is proposed; the type strain is Ch-32 ${ }^{\top}\left(=\right.$ CECT $7279^{\top}=$ DSM $\left.19417^{\top}\right)$.
\end{abstract}

The sweet chestnut (Castanea sativa Miller) has been cultivated systematically throughout Europe since the Middle Ages (Conedera et al., 2004) and covers large areas in the Mediterranean basin and the UK, being used for both nut and wood production (Fernández-López \& Alía, 2003). The leaves of the sweet chestnut remain on the tree for some time after drying and this stage may be considered to be the first step in degradation processes in which polymer-degrading bacteria are involved. In the case of the phyllosphere of palm tree bracts, several of these bacteria have been found (Rivas et al., 2007), mostly belonging to the genus Paenibacillus, e.g. Paenibacillus phyllosphaerae and Paenibacillus cellulosilyticus (Rivas et al., 2005, 2006). In this study, a bacterial strain, Ch- $32^{\mathrm{T}}$, was isolated from the phyllosphere of Castanea sativa growing in the Sierra de Francia (Salamanca, Spain) and, based on genotypic and phenotypic characterization, it should be classified as a novel species of the genus Paenibacillus.

Strain $\mathrm{Ch}-32^{\mathrm{T}}$ was isolated as follows. Chestnut leaves were immersed in $50 \mathrm{ml}$ pre-chilled buffer $(0.1 \mathrm{M}$ potassium

The GenBank/EMBL/DDBJ accession number for the 16S rRNA gene sequence of $P$. castaneae Ch-32 ${ }^{\top}$ is EU099594.

An extended phylogenetic tree constructed using the neighbour-joining method and based on 16S rRNA gene sequences of Paenibacillus castaneae $\mathrm{Ch}-32^{\top}$ and related species of Paenibacillus and Cohnella is available with the online version of this paper. phosphate, $\mathrm{pH} 7.0 ; 0.1 \%$ peptone) and sonicated for $10 \mathrm{~min}$ in an ultrasonic bath; samples $(0.1 \mathrm{ml})$ were then plated on tryptic soy agar medium containing cycloheximide $\left(0.15 \mathrm{mg} \mathrm{ml}^{-1}\right)$ and incubated at $30{ }^{\circ} \mathrm{C}$. The isolate was subcultured through two rounds of single-colony purification and subsequently stored at $-70{ }^{\circ} \mathrm{C}$ in $15 \%$ glycerol. On nutrient agar, colonies of strain $\mathrm{Ch}-32^{\mathrm{T}}$ were yellow, round, smooth and convex with approximate diameters of $1-3 \mathrm{~mm}$.

Strain Ch-32 ${ }^{\mathrm{T}}$ was grown in nutrient agar for $48 \mathrm{~h}$ at $22{ }^{\circ} \mathrm{C}$ to check for motility by phase-contrast microscopy using the hanging drop method. Gram staining was carried out by the procedure described by Doetsch (1981) after $24 \mathrm{~h}$ incubation at $30{ }^{\circ} \mathrm{C}$. The flagellation type was determined by electron microscopy after $48 \mathrm{~h}$ incubation of strain Ch- $32^{\mathrm{T}}$ in nutrient agar at $22{ }^{\circ} \mathrm{C}$ as described previously (Rivas et al., 2005). Strain Ch-32 ${ }^{\mathrm{T}}$ was Gram-variable and motile by means of polar and subpolar flagella. Ellipsoidal subterminal spores were formed in swollen sporangia.

The 16S rRNA gene of strain $\mathrm{Ch}-32^{\mathrm{T}}$ was analysed as described by Rivas et al. (2007). The sequence obtained was compared with those from GenBank using the programs BLASTN (Altschul et al., 1990) and EZTAXON (Chun et al., 2007). Sequences were aligned using CLUSTAL_X software (Thompson et al., 1997). Distances were calculated according to Kimura's two-parameter method (Kimura, 1980). The 
phylogenetic tree was inferred using the neighbour-joining method (Saitou \& Nei, 1987). Bootstrap analysis was based on 1000 resamplings. The MEGA2.1 software package (Kumar et al., 2001) was used for all analyses. The resulting neighbour-joining tree based on $16 \mathrm{~S}$ rRNA gene sequences is shown in Fig. 1 (an extended tree, supplementary Fig. S1, is available in IJSEM Online). Similar results were obtained using the maximum-parsimony method (data not shown). The results of the phylogenetic analysis indicated that strain Ch- $32^{\mathrm{T}}$ is related to members of the genus Paenibacillus. Strain Ch- $32^{\mathrm{T}}$ formed a cluster with Paenibacillus glycanilyticus DS- $1^{\mathrm{T}}$, Paenibacillus xinjiangensis $\mathrm{B}^{2} 38^{\mathrm{T}}$, Paenibacillus alkaliterrae KSL-134 ${ }^{\mathrm{T}}$, Paenibacillus agarexedens DSM $1327^{\mathrm{T}}$ and Paenibacillus agaridevorans DSM $1355^{\mathrm{T}}$ with gene sequence similarities of $97.7,97.0,96.9,96.5$ and $96.2 \%$, respectively.

For base composition analysis, DNA was prepared according to Chun \& Goodfellow (1995). The DNA $\mathrm{G}+\mathrm{C}$ content of strain $\mathrm{Ch}-32^{\mathrm{T}}$ was $46.0 \mathrm{~mol} \%$, determined using the thermal denaturation method (Mandel \& Marmur, 1968). DNA-DNA hybridization was performed by using the method of Ezaki et al. (1989) following the recommendations of Willems et al. (2001). DNA-DNA relatedness values for strain $\mathrm{Ch}-32^{\mathrm{T}}$ with $P$. glycanilyticus IFO $16618^{\mathrm{T}}$ and $P$. xinjiangensis DSM $16970^{\mathrm{T}}$ were lower than $20 \%$; this suggested that the isolate was not closely related to known species according to the current species concept (Wayne et al., 1987).

Chemotaxonomic analyses were carried out by the Identification Service of the DSMZ (Braunschweig,
Germany). Respiratory quinones were analysed as described by Tindall (1990) and cellular fatty acids were analysed according to the instructions of the Microbial Identification System (MIDI; Microbial ID). The menaquinone MK-7 was the only major respiratory quinone detected in strain Ch- $32^{\mathrm{T}}$. The fatty acid profile comprised anteiso- $\mathrm{C}_{15: 0}$ $(65.17 \%), \mathrm{C}_{16: 0}(9.53 \%)$, iso- $\mathrm{C}_{16: 0}(8.67 \%)$, iso- $\mathrm{C}_{15: 0}$ (5.42\%), anteiso- $\mathrm{C}_{17: 0}(4.20 \%)$, iso- $\mathrm{C}_{14: 0}(2.10 \%), \mathrm{C}_{15: 0}$ $(1.92 \%), \mathrm{C}_{14: 0}(1.55 \%)$ and iso- $\mathrm{C}_{17: 0}(1.45 \%)$. The fatty acid profile of strain Ch- $32^{\mathrm{T}}$ differed from those of the phylogenetically related species $P$. glycanilyticus IFO $16618^{\mathrm{T}}$ in the proportions of both anteiso- $\mathrm{C}_{15: 0}$ and iso- $\mathrm{C}_{16: 0}$ and it differed from that of $P$. xinjiangensis DSM $16970^{\mathrm{T}}$ in the proportion of anteiso- $\mathrm{C}_{15: 0}$ (Table 1 ).

Phenotypic characterization was performed according to standard methods described by Claus \& Berkeley (1986) and Logan \& Berkeley (1984) and by using the API $50 \mathrm{CH}$ (with $\mathrm{CHB} / \mathrm{E}$ medium), API 20NE and API 20E systems (bioMérieux) according to the manufacturer's instructions. Anaerobic growth was tested in fluid tetrathionate medium (Sigma). Acetoin production, the ability to grow in 2, 5 and $7 \% \mathrm{NaCl}$, nitrate reduction and phenylalanine deaminase, catalase, caseinase and oxidase activities were analysed as described by Claus \& Berkeley (1986). Acid production from glucose, xylose, mannitol and L-arabinose, and gas from glucose were analysed in liquid medium as described by Claus \& Berkeley (1986). Amylases and cellulases were analysed as described previously (Rivas et al. 2003). Growth was determined in temperatures ranging from 4 to $45{ }^{\circ} \mathrm{C}$ in YED medium $(0.5 \%$ yeast extract, $0.7 \%$ glucose and $2 \%$ agar). Growth at pH 5.7 and 6.8 was tested as described by

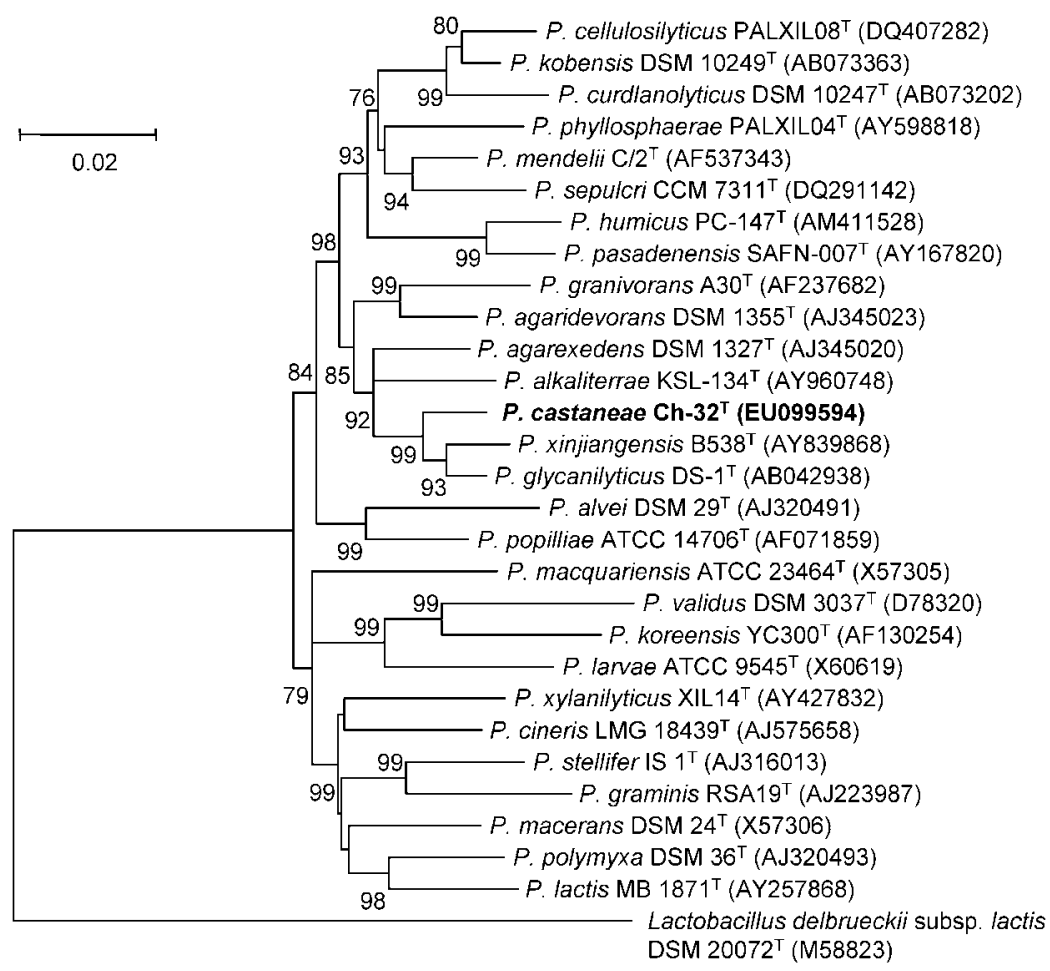

Fig. 1. Neighbour-joining tree based on nearly complete 16S rRNA gene sequences showing the relatedness between Paenibacillus castaneae $\mathrm{Ch}-32^{\top}$ and representative species of the genus Paenibacillus. Lactobacillus delbrueckii subsp. lactis DSM $20072^{\top}$ was used as outgroup. The significance of each branch is indicated by a bootstrap value calculated for 1000 subsets. Bar, 2 nt substitution per $100 \mathrm{nt}$. 
Table 1. Cellular fatty acid composition (\%) of strain Ch-32 ${ }^{\top}$ and related type strains

Strains: 1 , strain Ch- $32^{\mathrm{T}}$ (data from this study); 2, P. glycanilyticus DS- $1^{\mathrm{T}}$ (data from this study); 3, P. xinjiangensis $\mathrm{B}^{2} 38^{\mathrm{T}}$ (Lim et al., 2006). ND, Not detected.

\begin{tabular}{|lccc|}
\hline Fatty acid & $\mathbf{1}$ & $\mathbf{2}$ & $\mathbf{3}$ \\
\hline Saturated straight-chain & & & \\
$\mathrm{C}_{14: 0}$ & 1.55 & 1.52 & 1.93 \\
$\mathrm{C}_{15: 0}$ & 1.92 & 2.10 & 3.44 \\
$\mathrm{C}_{16: 0}$ & 9.53 & 8.71 & 14.43 \\
$\mathrm{C}_{16: 0} 3-\mathrm{OH}$ & $\mathrm{ND}$ & $\mathrm{ND}$ & $\mathrm{ND}$ \\
$\mathrm{C}_{17: 0}$ & $\mathrm{ND}$ & 0.22 & $\mathrm{ND}$ \\
$\mathrm{C}_{18: 0}$ & $\mathrm{ND}$ & 0.40 & $\mathrm{ND}$ \\
Saturated iso-branched & & & \\
$\mathrm{C}_{14: 0}$ & 2.10 & 3.33 & 2.12 \\
$\mathrm{C}_{15: 0}$ & 5.42 & 6.24 & 9.32 \\
$\mathrm{C}_{16: 0}$ & 8.67 & 23.79 & 9.62 \\
$\mathrm{C}_{17: 0}$ & 1.45 & 1.75 & 3.54 \\
Saturated anteiso-branched & & & \\
$\mathrm{C}_{15: 0}$ & 65.17 & 47.50 & 48.61 \\
$\mathrm{C}_{17: 0}$ & 4.20 & 3.53 & 4.40 \\
Unsaturated & & & \\
$\mathrm{C}_{16: 1} \omega 7 c$ & $\mathrm{ND}$ & $\mathrm{ND}$ & 0.53 \\
\hline
\end{tabular}

Claus \& Berkeley (1986). Growth at pH 7-8 was tested in YED medium containing $100 \mathrm{mM} \mathrm{Na} \mathrm{HPO}_{4} / \mathrm{NaH}_{2} \mathrm{PO}_{4}$ and growth at $\mathrm{pH} 9$ and 10 was tested in the same medium containing $100 \mathrm{mM} \mathrm{NaHCO} / \mathrm{Na}_{2} \mathrm{CO}_{3}$. Results are given in the species description below. Strain $\mathrm{Ch}-32^{\mathrm{T}}$ could be differentiated from the closely related species $P$. glycanilyticus by growth at $40{ }^{\circ} \mathrm{C}$, gelatin and starch hydrolysis, and assimilation of fructose, $\mathrm{N}$-acetylglucosamine, adipate and phenylacetate as carbon sources, and from $P$. xinjiangensis by its ability to grow at $\mathrm{pH} 5.7$, acetoin production, gelatin hydrolysis, and assimilation of fructose, mannitol, adipate and phenylacetate as carbon sources (Table 2).

Therefore, strain Ch- $32^{\mathrm{T}}$ can be differentiated genotypically and phenotypically from previously described species and it is proposed that it should be classified as a novel species, Paenibacillus castaneae sp. nov.

\section{Description of Paenibacillus castaneae sp. nov.}

Paenibacillus castaneae (cas.ta.ne' ae. L. gen. n. castaneae of a chestnut tree).

Cells of the single isolate of this species (strain $\mathrm{Ch}-32^{\mathrm{T}}$ ) are Gram-variable and motile by means of polar and subpolar flagella. No chains are formed. Ellipsoidal subterminal spores are formed in swollen sporangia. Catalase- and oxidase-positive. Colonies on nutrient agar medium are yellow, round, smooth and convex with approximate

Table 2. Differential phenotypic characteristics of Paenibacillus castaneae sp. nov. and phylogenetically related species of the genus Paenibacillus

Species: 1, P. castaneae Ch- $32^{\mathrm{T}}$ (data from this study); 2, P. glycanilyticus [data from Dasman et al. (2002) and Yoon et al. (2005) for the type strain]; 3 P. xinjiangensis (Lim et al., 2006); 4, P. alkaliterrae (Yoon et al., 2005); 5, P. agarexedens [Uetanabaro et al. (2003) and Yoon et al. (2005) for the type strain]; 6, P. agaridevorans [Uetanabaro et al. (2003) and Yoon et al. (2005) for the type strain]. +, Positive reaction; -, negative reaction; w, weakly positive reaction; ND, not determined; v, variable reaction. Data in parentheses are for type strains (Yoon et al., 2005). All species are negative for anaerobic growth and nitrate reduction.

\begin{tabular}{|c|c|c|c|c|c|c|}
\hline Characteristic & 1 & 2 & 3 & 4 & 5 & 6 \\
\hline Gram stain & $\mathrm{v}$ & + & + & + & $\mathrm{v} /-$ & $\mathrm{v} /-$ \\
\hline Colony colour & Yellow & Pinkish yellow & White-cream & White-cream & White-cream & White-cream \\
\hline Oxidase & + & $+{ }^{*} \dagger$ & $+\dagger$ & + & + & + \\
\hline \multicolumn{7}{|l|}{ Growth at: } \\
\hline pH 5.7 & + & + & - & - & - & - \\
\hline $40{ }^{\circ} \mathrm{C}$ & - & + & $-\dagger$ & - & $\mathrm{V}(-)$ & - \\
\hline Voges-Proskauer reaction & - & - & $+\dagger$ & - & - & - \\
\hline \multicolumn{7}{|l|}{ Hydrolysis of: } \\
\hline Gelatin & + & - & $-\dagger$ & - & - & - \\
\hline Starch & $-\ddagger$ & + & - & + & + & $-\ddagger$ \\
\hline \multicolumn{7}{|l|}{ Assimilation of: } \\
\hline D-Mannose & + & + & + & + & $+\dagger$ & $(-)$ \\
\hline Fructose & - & + & + & + & $(-)$ & $(-)$ \\
\hline Mannitol & + & + & - & $-\dagger$ & $-\dagger$ & ND \\
\hline$N$-Acetylglucosamine & - & + & $\mathrm{w} \dagger$ & $-\dagger$ & $\mathrm{w} \dagger$ & $\mathrm{ND}$ \\
\hline
\end{tabular}

*Oxidase was reported as negative by Yoon et al. (2005).

$\dagger$ Data from this study.

\$Negative in flooding with Lugol’s iodine solution. 
diameters of $1-3 \mathrm{~mm}$. The only major quinone is MK-7. The main fatty acids are anteiso- $\mathrm{C}_{15: 0}$, iso- $\mathrm{C}_{16: 0}$ and $\mathrm{C}_{16: 0}$. Negative in tests for anaerobic growth. Grows at $\mathrm{pH}$ 5.7; optimal pH is 7 . Grows in $2 \% \mathrm{NaCl}$, but not in $5 \% \mathrm{NaCl}$. Optimal growth temperature is $30{ }^{\circ} \mathrm{C}$; unable to grow at $40{ }^{\circ} \mathrm{C}$. Nitrate is not reduced to nitrite. Produces $\beta$ galactosidase, but not acetoin, indole, phenylalanine deaminase, urease, arginine dihydrolase, ornithine decarboxylase or lysine decarboxylase. Hydrolyses aesculin, gelatin and cellulose, but not starch or casein. In the API 20NE system, positive for assimilation of glucose, Larabinose, mannose, mannitol, maltose and gluconate, but negative for that of $\mathrm{N}$-acetylglucosamine, caprate, citrate, adipate, L-malate and phenylacetate. Acid, but not gas, is produced from glucose. In the API $50 \mathrm{CH}$ system, positive for acid production from L-arabinose, D-xylose, methyl $\beta$-D-xyloside, galactose, D-glucose, mannose, Lrhamnose, mannitol, maltose, melibiose, sucrose, trehalose, raffinose, gentiobiose and turanose, but negative for acid production from glycerol, erythritol, D-ribose, L-xylose, adonitol, fructose, L-sorbose, inositol, sorbitol, methyl $\alpha$-Dmannoside, methyl $\alpha$-D-glucoside, $N$-acetylglucosamine, amygdalin, cellobiose, melezitose, glycogen, xylitol, Llyxose, D-tagatose, D-fucose, L-fucose, D-arabitol and Larabitol. Acid production from salicin and lactose is weak.

The type strain is Ch $-32^{\mathrm{T}}\left(=\right.$ CECT $7279^{\mathrm{T}}=$ DSM $\left.19417^{\mathrm{T}}\right)$, isolated from the phyllosphere of chestnut trees growing in the Sierra de Francia region, Salamanca province, Spain. The $\mathrm{G}+\mathrm{C}$ content of the type strain is $46.0 \mathrm{~mol} \%$.

\section{Acknowledgements}

This work was supported by grant no. QLK5-CT-2001-00029 (MANCHEST project) from the European Union. We thank Dr J. P. Euzéby for etymological advice and Dr B. Tindall for the fatty acid analysis.

\section{References}

Altschul, S. F., Gish, W., Miller, W., Myers, E. W. \& Lipman, D. J. (1990). Basic local alignment search tool. J Mol Biol 215, 403-410.

Chun, J. \& Goodfellow, M. (1995). A phylogenetic analysis of the genus Nocardia with 16S rRNA gene sequences. Int J Syst Bacteriol 45, 240-245.

Chun, J., Lee, J.-H., Jung, Y., Kim, M., Kim, S., Kim, B. K. \& Lim, Y.-W. (2007). EzTaxon: a web-based tool for the identification of prokaryotes based on 16 S ribosomal RNA gene sequences. Int J Syst Evol Microbiol 57, 2259-2261.

Claus, D. \& Berkeley, R. C. W. (1986). Genus Bacillus Cohn 1872, $174^{\mathrm{AL}}$. In Bergey's Manual of Systematic Bacteriology, vol. 2, pp. 11051140. Edited by P. H. A. Sneath, N. S. Mair, M. E. Sharpe \& J. G. Holt. Baltimore: Williams \& Wilkins.

Conedera, M., Krebs, P., Tinner, W., Pradella, M. \& Torriani, D. (2004). The cultivation of Castanea sativa (Mill.) in Europe, from its origin to its diffusion on a continental scale. Veg Hist Archaeobot 13, 161-179.

Dasman, Kajiyama, S., Kawasaki, H., Yagi, M., Seki, T., Fukusaki, E. \& Kobayashi, A. (2002). Paenibacillus glycanilyticus sp. nov., a novel species that degrades heteropolysaccharide produced by the cyanobacterium Nostoc commune. Int J Syst Evol Microbiol 52, 1669-1674.

Doetsch, R. N. (1981). Determinative methods of light microscopy. In Manual of Methods for General Bacteriology, pp. 21-33. Edited by P. Gerhardt, R. G. E. Murray, R. N. Costilow, E.W. Nester, W. A. Wood, N. R. Krieg \& G. B. Phillips. Washington, DC: American Society for Microbiology.

Ezaki, T., Hashimoto, Y. \& Yabuuchi, E. (1989). Fluorometric deoxyribonucleic acid-deoxyribonucleic acid hybridization in microdilution wells as an alternative to membrane filter hybridization in which radioisotopes are used to determine genetic relatedness among bacterial strains. Int J Syst Bacteriol 39, 224-229.

Fernández-López, J. \& Alía, R. (2003). EUFORGEN Technical Guidelines for genetic conservation and use for chestnut (Castanea sativa). Rome, Italy: International Plant Genetic Resources Institute.

Kimura, M. (1980). A simple method for estimating evolutionary rates of base substitutions through comparative studies of nucleotide sequences. J Mol Evol 16, 111-120.

Kumar, S., Tamura, K., Jakobsen, I. B. \& Nei, M. (2001). MEGA2: molecular evolutionary genetics analysis software. Bioinformatics $\mathbf{1 7}$, 1244-1245.

Lim, J. M., Jeon, C. O., Park, D. J., Xu, L. H., Jiang, C. L. \& Kim, C. J. (2006). Paenibacillus xinjiangensis sp. nov., isolated from Xinjiang province in China. Int J Syst Evol Microbiol 56, 2579-2582.

Logan, N. A. \& Berkeley, R. C. W. (1984). Identification of Bacillus strains using the API system. J Gen Microbiol 130, 1871-1882.

Mandel, M. \& Marmur, J. (1968). Use of ultraviolet absorbancetemperature profile for determining the guanine plus cytosine content of DNA. Methods Enzymol 12B, 195-206.

Rivas, R., Sánchez, M., Trujillo, M. E., Zurdo-Piñeiro, J. L., Mateos, P. F., Martínez-Molina, E. \& Velázquez, E. (2003). Xylanimonas cellulosilytica gen. nov., sp. nov., a xylanolytic bacterium isolated from a decayed tree (Ulmus nigra). Int J Syst Evol Microbiol 53, 99-103.

Rivas, R., Mateos, P. F., Martínez-Molina, E. \& Velázquez, E. (2005). Paenibacillus phyllosphaerae sp. nov., a xylanolytic bacterium isolated from the phyllosphere of Phoenix dactylifera. Int J Syst Evol Microbiol 55, 743-746.

Rivas, R., García-Fraile, P., Mateos, P. F., Martínez-Molina, E. \& Velázquez, E. (2006). Paenibacillus cellulosilyticus sp. nov., a cellulolytic and xylanolytic bacterium isolated from the bract phyllosphere of Phoenix dactylifera. Int J Syst Evol Microbiol 56, 2777-2781.

Rivas, R., García-Fraile, P., Mateos, P. F., Martínez-Molina, E. \& Velázquez, E. (2007). Characterization of xylanolytic bacteria present in the bract phyllosphere of the date palm Phoenix dactylifera. Lett Appl Microbiol 44, 181-187.

Saitou, N. \& Nei, M. (1987). The neighbor-joining method: a new method for reconstructing phylogenetic trees. Mol Biol Evol 4, 406-425.

Thompson, J. D., Gibson, T. J., Plewniak, F., Jeanmougin, F. \& Higgins, D. G. (1997). The CLUSTAL_X windows interface: flexible strategies for multiple sequence alignment aided by quality analysis tools. Nucleic Acids Res 25, 4876-4882.

Tindall, B. J. (1990). Lipid composition of Halobacterium lacusprofundi. FEMS Microbiol Lett 66, 199-202.

Uetanabaro, A. P., Wahrenburg, C., Hunger, W., Pukall, R., Spröer, C., Stackebrandt, E., de Canhos, V. P., Claus, D. \& Fritze, D. (2003). Paenibacillus agarexedens sp. nov., nom. rev., and Paenibacillus agaridevorans sp. nov. Int J Syst Evol Microbiol 53, 1051-1057.

Wayne, L. G., Brenner, D. J., Colwell, R. R., Grimont, P. A. D., Kandler, O., Krichevsky, M. I., Moore, L. H., Moore, W. E. C., Murray, R. G. E. \& 
other authors (1987). International Committee on Systematic Bacteriology. Report of the ad hoc committee on reconciliation of approaches to bacterial systematics. Int J Syst Bacteriol 37, 463-464.

Willems, A., Doignon-Bourcier, F., Goris, J., Coopman, R., de Lajudie, P., De Vos, P. \& Gillis, M. (2001). DNA-DNA hybridization study of Bradyrhizobium strains. Int J Syst Evol Microbiol 51, 1315-1322.

Yoon, J. H., Kang, S. J., Yeo, S. H. \& Oh, T. K. (2005). Paenibacillus alkaliterrae sp. nov., isolated from an alkaline soil in Korea. Int J Syst Evol Microbiol 55, 2339-2344. 